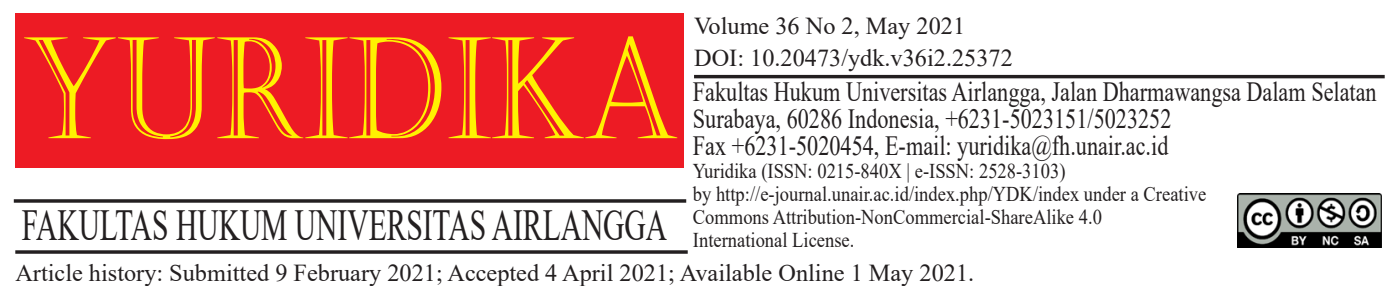

\title{
The Use of Receivables as Collateral in Business Practices in Indonesia
}

\author{
Rio Christiawan \\ rchristiawan@gmail.com \\ Universitas 17 Agustus 1945 Jakarta
}

\begin{abstract}
This article discusses the enforceability of article 9 of Law No 42 of 1999 on Fiduciary Guarantee that allows the use of receivables as debt collateral in business practices in Indonesia. Receivables bound by fiduciary collateral are deemed special collateral in the context of civil law. Special collateral will be prioritised in case the debtor does not voluntarily make when due. In business practices, long-term receivables will be established following an agreement between a debtor and a third party. The receivables that the debtor is entitled to receive from the third party will be provided as collateral to secure the debtor's obligations under his loan agreement with the creditor. The issue discussed in this paper is the fact that although theoretically, special collateral in the form of receivables should be able to increase the creditor's assurance of getting repaid, in practice, long-term receivables put higher risk on the creditor instead. This paper adopts the normative juridical approach, focusing on juridical studies regarding the creditors' risk in the use of receivables, specifically long-term debt collateral. This paper shows that receivables used as collateral in fiduciary agreements put the greatest risk on the creditor, especially if the agreement between the debtor and the third-party stipulates that in case the debtor fails to fulfil his obligations, all receivables that he is supposed to receive from the third party will be aborted and become non-existent. Keywords: Risk; Receivables; Fiduciary Guarantee.
\end{abstract}

\section{Introduction}

The academic paper on Law No 42 of 1999 on Fiduciary Guarantee (Fiduciary Guarantee Law) states that article 9 is intended to provide business flexibility after the 1998 economic crisis. Furthermore, the academic text defines business flexibility as a form of solution for debtors to get financing while still ensuring that the creditors will be repaid. ${ }^{1}$

1 Tim Penyusun Naskah Akademis Undang-Undang Fidusia, Pokok-Pokok Rancangan Undang-Undang Fidusia (Kementerian Hukum dan Hak Asasi Manusia 1999). [56]. 
Article 1 paragraph (3) of the Fiduciary Guarantee Law defines receivables as the right to receive payments, which means a fiduciary guarantee only provides the creditor a right to be paid by the debtor from the receivables the debtor is entitled to receive from a third party. In civil law, the term 'rights' refers to everything that will be obtained once an obligation is fulfilled; if the debtor fails to fulfil his obligations to the third party, then the right to receivables will not be obtained. ${ }^{2}$ In short, the receivables referred to in article 1 paragraph (3) of the Fiduciary Guarantee Law may not be paid because the payment of such receivables highly depends on the fulfilment of the debtor's obligations to the third party. Only if the debtor manages to fulfil his obligations will the third party pay him. ${ }^{3}$

In its civil construction, a collateral agreement will only exist after the establishment of a loan agreement between a creditor and a debtor. Special collateral in the form of receivables is intended to guarantee the repayment of debts to creditors. Referring to article 9 paragraph (1) of the Fiduciary Guarantee Law, the phrase '...including receivables, whether existing at the time the guarantee is given or acquired later...' implies a possibility that the debtor will not be able to obtain the receivables.

The use of receivables as collateral is said to put the largest portion of risk on creditors because a third party's payments to debtors are conditional. It contains a condition precedent, depending on the debtor's fulfilment of contractual obligations toward the third parties. Receivables and payments received by debtors - which are used as special collateral for the debts to creditors - are subject to a condition precedent, which means that if the debtors do not fulfil their contractual obligations to third parties, the collateral object will not exist.

In civil law, a condition precedent is defined as the prerequisite for the fulfilment of conditions. ${ }^{4}$ Receivables arising from contractual agreements will

\footnotetext{
${ }^{2}$ Toni Prasetiyantono, Restrukturisasi Pembiayaan Bermasalah (BI Press 2017).[38].

${ }^{3}$ Munir Fuady, Pengantar Hukum Bisnis: Menata Bisnis Modern Di Era Global (2015).[112].

${ }^{4}$ Thomas Maquez, Principle of Financial Feasibility (McGraw Publishing Co Cincinnati Press 2016).[40].
} 
always have a condition precedent in the form of a debtor's fulfilment toward its contractual obligations. Should the debtor manage to fulfil his obligations, his right to receive payment from the third party/his receivables will be paid. Conversely, if he fails to fulfil his obligations, his receivables will not be paid. Instead, he will be considered to owe the third party. Such a situation is stipulated in article 1263 of the Indonesian Civil Code and is known as an obligation with conditions of deferment. ${ }^{5}$ Thus, the execution of such collateral with conditions of deferment will put the creditor in a risky place. ${ }^{6}$

In the Civil Code, the transfer of property rights as collateral is stipulated in articles 584 and 612 paragraph (1), in case the transfer of property rights fiduciary guarantee solely acts as collateral for debt payment and not to be permanently owned by the fiduciary receiver. From a legal perspective, a fiduciary accounts receivable is an agreement for the granting of guarantees, the object of which is not controlled by the guarantor. This is contrary to the prohibition of article 1152 paragraph (2) of the Civil Code. On the other hand, the fiduciary legal construction of accounts receivable in article 9 paragraph (1) of the Fiduciary Guarantee Law is fiducia cum creditore. The transfer of property rights will occur perfectly so that the fiduciary recipient (creditor) has the position of the perfect owner as well. It is just that the creditor is obliged to return the property rights (in this case, in the form of receivables) to the debtor who provides the fiduciary if the debtor has paid off the debt. This means that it depends on the conditions in the agreement. The right of a new fiduciary recipient is born perfectly if the fiduciary does not fulfil his obligations (the debtor goes default). ${ }^{7}$

\footnotetext{
${ }^{5}$ In the Indonesian Civil Code, the term 'condition precedent' is translated as conditions of deferment as stipulated in article 1263, in which an obligation with conditions of deferment is defined as an obligation that is contingent on a future event that is not certain to occur, or on an event that has already occurred but is not known to the parties.

${ }^{6}$ Toto Octaviano Dendhana, 'Penerapan Prudential Banking Priciple Dalam Upaya Perlindungan Hukum Bagi Nasabah’ (2013) 1 Jurnal Lex Et Sociatatis Universitas Sam Ratulangi.[12].

${ }^{7}$ Marulak Pardede, [et.,al], Laporan Akhir Penelitian Hukum: Implementasi Jaminan Fidusia Dalam Pemberian Kredit Di Indonesia (Badan Pembinaan Hukum Nasional Departemen Hukum dan Hak Asasi Manusia Republik Indonesia 2006).[29].
} 
This situation contradicts the purpose of special collateral itself (in this case, fiduciary collateral/guarantee). One of the characteristics of special collateral is that it must be easy to enforce. This characteristic is based on the consideration that in special collateral, the debtor has bound himself with the creditor to provide guarantees specifically to the creditor in the form of objects owned by the debtor to guarantee the debtor's obligations in accordance with the principal agreement if the debtor defaults. ${ }^{8}$ The issue to be discussed in this paper is how fiduciary guarantees in the form of receivables protect the interests of creditors if the debtor does not fulfil his contractual obligations toward the third party.

\section{Cessie with Conditions of Deferment}

The provisions in the Fiduciary Guarantee Law concerning receivables as fiduciary collateral are an important breakthrough considering that generally, the objects of fiduciary collateral are movable. This condition is the main reason cessie as collateral does not protect creditors holding cessie as collateral. Furthermore, the Fiduciary Guarantee Law specifically regulates in article 23 paragraph (1) that the use, transfer of objects, or the results of objects to become objects of fiduciary security approved by the fiduciary recipient does not result in the loss of fiduciary security for certain objects. Furthermore, in article 23 paragraph (2), to multiply, pawn, or lease to another party objects that are the object of fiduciary security which are not inventory objects, except with prior written approval from the fiduciary recipient.

According to the Ministry of Finance of the Republic of Indonesia, cessie is a transfer of intangible goods rights that are usually in the form of receivables on behalf of third parties. ${ }^{9}$ Agreement is one source that can lead to engagement. The meaning of an engagement is a legal relationship between two people or two

\footnotetext{
${ }^{8}$ Risalah Keterangan Ahli Akhmad Budi Cahyono dalam persidangan Mahkamah Konstitusi Nomor 18/PUU-XVII/2019 terkait Pengujian Pasal 15 Undang-Undang Nomor 42 Tahun 1999 tentang Jaminan Fidusia.

${ }^{9}$ Margono Dwi Susilo, 'Lelang Hak Tagih? Mengapa Tidak' (Direktorat Jenderal Kekayaan Negara Kementerian Keuangan, 2018) <www.djkn.kemenkeu.go.id/artikel/baca/12717/LelangHak-Tagih-Mengapa-TIdak.html> accessed 2 September 2020.
} 
parties, based on which one party has the right to demand something from the other party, and the other party is obliged to fulfil that demand..$^{10}$

Article 613 paragraph (1) of the Indonesian Civil Code explains that the transfer of receivables and other intangible properties, which will come into effect by using an authentic or private deed that transfers the rights to such objects to another individual, shows that the receivables must have already been in existence. It is important to note that this is different from the provision in article 9 paragraph (1) of the Fiduciary Guarantee Law, which allows receivables that have yet to exist to be used as collateral.

In business practice in Indonesia, the value of a collateral is based on the parties' agreement as stated in the contract. ${ }^{11}$ The value of receivables is determined based on what is written in the agreement between the debtor and third-party, without considering the possibility that the debtor may fail to fulfil his contractual obligations. ${ }^{12}$ Such value is what becomes the object of collateral agreement - in this case, the fiduciary guarantee agreement. In accordance with Indonesian civil law, collateral in the form of receivables will arise through two contractual agreements: (i) the loan agreement between creditor and debtor, which is guaranteed with the debtor's receivables that he will receive after fulfilling his obligations toward the third party, and (ii) his agreement with a third party. The risk of transfer of receivables (cessie) arises from the fact that the debtor may not be able to fulfil his contractual obligations. Cessie will only occur if the conditions of deferment agreed upon by the debtor and creditor are fulfilled.

Conversely, the definition of conditions of deferment in the issuance of receivables as collateral is a situation where the debtor is unable to fulfil his contractual obligations to the third party, resulting in the cancellation of the

\footnotetext{
${ }^{10}$ Maulidiazeta Wiriardi, 'Prinsip-Prinsip Hukum Perjanjian Dalam Kesepakatan Para Pihak Yang Bersengketa Atas Permohonan Intervensi Pihak Ketiga Dalam Undang-Undang Nomor 30 Tahun 1999 Tentang Arbitrase Dan Alternatif Penyelesaian Sengketa' (2011) 26 Jurnal Yuridika Universitas Airlangga.[72].

${ }^{11}$ Gunarto Suhardi, Valuasi Jaminan Perbankan (Untag Press 2015).[88].

${ }^{12}$ Liliana Tedjasaputra, Pedoman Pengikatan Fidusia Bagi Notaris (Ghalia Indah 2016).[79].
} 
receivables that he was going to use as collateral. This puts the creditor in the riskiest and most vulnerable state because the loan agreement between the creditor and debtor is already in effect. There is no guarantee that the collateral will be paid because there will always be the possibility that the debtor fails to fulfil his obligations to the third party.

Under Indonesian law, conditions of deferment are defined as a prerequisite for the fulfilment of conditions. In this case, it is a prerequisite for the existence of receivables that act as collateral in a loan agreement between the debtor and creditor. This means that if the prerequisites for the receivables between the debtor and the third party are not fulfilled, the receivables used as collateral will never be paid. This dilemma shows the inconsistency between the provisions of article 613 paragraph (1) of the Indonesian Civil Code and article 9 paragraph (1) of the Fiduciary Guarantee Law.

In the interpretation of article 613 paragraph (1) of the Indonesian Civil Code, by law cessie occurs when the debtor is declared unable to fulfil his obligations to the creditor, and the receivables will be considered a payment of the debtor's obligations to the creditor. Meanwhile, article 9 paragraph (1) of the Fiduciary Guarantee Law creates a loophole for conditions of deferment that makes the existence of receivables depend solely on the fulfilment of contractual obligations between the debtor and the third party. This uncertainty causes an imbalance of power between the creditor and the debtor, in which the creditor's position is weaker. The creditor has given a loan to the debtor, but the collateral guarantees given by the debtor are solely dependent on the fulfilment of conditions of deferment, which means they may not necessarily come true.

The risk for creditors providing loans with receivables as collateral is the punctual repayment and fulfilment of the outstanding loan along with other obligations that will depend largely on the good intentions of the debtor. In the event that the debtor does not fulfil his obligations to the creditor, and at the same time the debtor also does not fulfil the conditions of deferment under the debtor and third party's agreements, then the debtor's default condition will not be able 
to be guaranteed by the receivables. The non-fulfilment of contractual obligations toward the third party will result in the annulment of the debtor's entitlement to the receivables.

Cessie cannot be done if the conditions of deferment of a receivables collateral are not fulfilled. This is a contrast to the essence of cessie in business practices, which is used as a form of settlement and payment between debtors and creditors. ${ }^{13}$ Theoretically speaking, cessie can be done voluntarily even with the existence of conditions of deferment because if the debtor fulfils all his obligations toward the creditor, the cessie will not need to happen.

Cessie itself is a way of converting receivables collateral bound in a fiduciary agreement. The nature of the collateral agreement is to follow the principal agreement, in this case, the principal (loan) agreement between the creditor and the debtor. The occurrence of cessie will depend on the fulfilment of the debtor's obligations to third parties that will issue receivables that will be used as collateral.

\section{Receivables as Collateral in England}

In the United Kingdom (UK), fiduciary security is an important concept within the legal system. The Judicature Acts combine equity courts (historically based at the Chancellery of England) with common law courts. As a result, the concept of fiduciary obligation also becomes applicable to the legal system in England.

Issues regarding cessie with conditions of deferment in Indonesia as described in the previous sub-chapter occur because of the inconsistency between article 613 paragraph (1) of the Indonesian Civil Code and article 9 paragraph (1) of the Fiduciary Guarantee Law. The asynchronous of the two regulations causes an unequal position between creditors and debtors in an agreement with receivables as collateral. This problem is inseparable from the historical factor, namely the civil law system in Indonesia that was originally guided by the Civil Code but later on, especially after the 1998 economic crisis, follows the provisions in Law Number 42

\footnotetext{
${ }^{13}$ Nindyo Pramono, Hukum Pembiayaan Dalam Praktik (Andi Offshet 2017).[109].
} 
of 1999 concerning Fiduciary Guarantee as a lex specialist. ${ }^{14}$

The concept of fiduciary guarantee itself originates from the common law system (anglo saxon). When the civil law system as applied in Indonesia only recognises general guarantees and special guarantees as stipulated in the Indonesian Civil Code, the common law system already regulates guarantees specifically based on the object of collateral and designation through separate statutory regulations so that they are more specialist in nature. ${ }^{15}$ In England, the fiduciary of stock item (floating charges) has been recognised by the court since 1870 in the Re Panama, New Zealand and Australian Royal Mail Co case. This case acknowledged for the first time the existence of a floating charge. It decided that the debenture holders had priority rights over the other creditors, and the rights apply to all of the company's (debtor's) property that existed in the present, past and future. After this case, in England, many other cases recognised fiduciary in the form of receivables. ${ }^{16}$

In the 1980s, the UK became more familiar with fiduciary registration institutions that issued fiduciary guarantee certificates as proof that a guarantee or collateral was bound through a fiduciary. ${ }^{17}$ In the case of Standard Chartered Bank against Sterling Capital, the London court in 2001 ruled that the information written in a fiduciary certificate is considered correct and was equated with an authentic deed. ${ }^{18}$

The credit verification agency was established under the coordination of the institution that issued fiduciary certificates. The purpose of establishing a credit verification agency is to ensure that the receivables that will become collateral are clear and clean or that the collateral guarantees bound by fiduciary agreements are executable. Likewise, in the UK, receivables that have not yet been issued cannot

\footnotetext{
${ }^{14}$ Yudha Ramelan, 'Perlindungan Terhadap Simpanan Pernah Tercatat Pada Bank, Bukan Suatu Keniscayaan’ (2019) 49 Jurnal Hukum dan Pembangunan Universitas Indonesia.[792].

15 Peter Schletriem, 'Financing Agreement in Civil Law and Common Law Practice' (2015) 53 Cornell International Law Journal.[290].

${ }^{16}$ Connor Ndulo, 'Legal Aspect of Financing Guarantee' (2016) 68 International and Comparative Law Quarterly Journal.[201].

${ }^{17}$ Sharon Dughton, Legal Case on Financial Default (West Publishing St Paul Minnesota 2017).[178].

${ }^{18}$ Gully Dean, 'Financing Transactions in Common Law and Civil Law Countries' (2018) 34 Temple International and Comparative Law Journal.[65].
} 
be used as collateral for debt agreements, the aim being that creditors and debtors can be in fair and balanced positions. This means that the debt agreement that has occurred between the creditor and the debtor is guaranteed with receivables that are already existing and have no legal problems to be transferred through the cessie mechanism should the debtor becomes unable to fulfil his obligations to the creditor at any given time. ${ }^{19}$

The difference with fiduciary rules in Indonesia is that the fiduciary regulations in the UK do not allow collaterals from receivables that do not yet exist or still depend on certain conditions. The UK legal provisions are made to create a balanced position between creditors and debtors in business practices and avoid potential legal disputes between the parties. ${ }^{20}$ In this case, the main task of the credit verification agency is to ensure that the guaranteed receivables do exist and there are no legal issues concerning them.

Additionally, the credit verification agency is also tasked with checking the substance and validity of the contractual agreements made by the debtor and the third party - a necessary step considering the condition of the receivables that become collateral will depend on the implementation of the contract between the debtor and the third party. ${ }^{21}$ Such procedure shows that the fiduciary guarantee itself has been through rapid changes in the UK.

The concept of fiduciary itself was originally about the transfer of ownership rights of an object (receivables in civil context is considered a material right as well) based on trust, provided that the object to which ownership rights are being transferred remains in the control of the owner of the object. At the time when fiduciary guarantees were first formed, from the perspective of sociology, the community was still a communal one, but as time went by, society shifted to a more individualistic culture. Still, a legal instrument for flexible collaterals or guarantees

\footnotetext{
${ }^{19}$ Hessel and King, Financing Case (McGraw Hill Book Publishing 2011).[90].

${ }^{20}$ Samual Kitt, Mortgage and Financing Law (Irvin Books Publishing 2017).[144].

${ }^{21}$ Peter Thre, Legal Aspect on Financing Transaction (Little Brown Publishing Canada 2019).[101].
} 
were necessary, and so in England, fiduciary is maintained with many adjustments. ${ }^{22}$

Some of these adjustments are intended to protect the interests of the parties involved, even though adjustments such as the establishment of fiduciary institutions, credit verification institutions and issuance of fiduciary certificates somehow reduced the weight of trust that is the philosophical basis of the birth of the fiduciary guarantee itself. Philosophically, the birth of a fiduciary guarantee is based on the principle of good faith that leads to trust. However, as more objects became available to be bound by fiduciary guarantee, the fiduciary institution had no choice but to follow the tide. This is what needs to be done in Indonesia, considering that when compared to the UK, the practice of implementing fiduciary guarantees in Indonesia both in terms of regulations and institutions still needs various major adjustments and improvements.

Fiduciary as collateral is nothing new because it has been used in the business world for a long time, both in Indonesia and other developed countries with variations. Sri Soedewi Masjchun Sofwan stated that historically speaking, fiduciary institutions with many variations have also been practised in several other developed countries such as England. ${ }^{23}$

In English, fiduciary as collateral is known as fiduciary transfer of ownership, which means it is based on trust. In various literature, fiduciary collateral is often referred to as eigendom overdract (FEO), which is a transfer of ownership rights based on trust. ${ }^{24}$ In Indonesia, in its history of growth, fiduciary institutions were first recognised by jurisprudence, such as the Oogstver band (Staatsblad 1886 Number 57) regarding money lending provided with harvest guarantees (account receivables), which refers to the law in England.

Fiduciary's growth was influenced by the urgent needs of small entrepreneurs, retailers, traders, medium-sized traders or wholesalers for credit facilities for their business, especially after the First World War, where the need for credit for small

\footnotetext{
${ }^{22}$ Michael Hill, Mortgage History (Intersciences Publishing 2011).[102].

${ }^{23}$ Munir Fuady, Jaminan Fidusia (Citra Aditya Bakti 2003).[13].

${ }^{24}$ Salim H S, Perkembangan Hukum Jaminan Di Indonesia (Raja Grafindo Persada 2014).[55].
} 
entrepreneurs was very high. Such credit needs, of course, required guarantees for the security of the creditors' capital. In such circumstances, it was impossible to use the mortgage institution because they did not have land as collateral. ${ }^{25}$

In Indonesia, fiduciary institutions were developed with reference to the Anglo Saxon legal model, especially English law. A special law regarding fiduciary collateral was issued, namely Law Number 42 of 1999. Meanwhile, in the Netherlands, fiduciary institutions have not existed since the introduction of the Niew Nederlands Burgerlijk Wetboek in 1992. ${ }^{26}$

\section{The Importance of Business Contract Formulation}

Considering the inconsistency between article 613 paragraph (1) of the Indonesian Civil Code and article 9 paragraph (1) of the Fiduciary Guarantee Law and the lack of institutions that verify receivables as they have in the UK, the formulation of business contracts between the parties becomes an important factor in maintaining equal positions between the parties. The decision of the Central Jakarta District Court Number 670/Pdt.G/2017/PN.JKT.PST explains that the validity of the receivables collaterals is determined from the implementation of the contractual agreements and obligations between the parties.

Furthermore, the Supreme Court of the Republic of Indonesia through Jurisprudence Number 1264/K/Pdt/2016 states that the validity of the implementation of agreements and contractual obligations between the parties includes two agreements: the loan agreement between the debtor and creditor; and the agreement between the debtor and the third party that will create the debtor's entitlement to receivables, which becomes the collateral for the former agreement. This means that if the latter agreement is cancelled or is declared null and void by law, it will affect the other's implementation. If the loan agreement between the debtor and the

\footnotetext{
${ }^{25}$ Andhika Desy Fluita and I Gusti Ayu K R H, 'Tinjauan Sejarah Lembaga Fidusia di Indonesia' (2017) 4 Jurnal Repertorium.[9].

${ }^{26}$ Sutan Remy Sjahdeini, 'Komentar Pasal Demi Pasal Undang-Undang No 42 Tahun 1999 tentang Jaminan Fidusia' (2000) 10 Jurnal Hukum Bisnis.[40].
} 
creditor is cancelled, it will affect the agreement between the debtor and the third party because in this case, the debtor's income and receivables from this transaction.

Conversely, if the agreement between the debtor and third party is cancelled, the receivables will no longer be available. Thus, to create a fair and balanced position between creditors and debtors, both agreements must be considered inseparable and are closely intertwined. Although it still will not fully guarantee the validity of the receivables as collateral, ideally, the creditor needs to conduct due diligence on the agreement and the implementation of the agreement between the debtor and the third party.

To avoid potential disputes, the role of credit verification institutions like the ones in the UK must be carried out independently by the creditor, bearing in mind the interests of the validity of the collateral are the interests of the creditor. Likewise, when the debtor is unable to fulfil his obligations, it is in the creditor's best interest to ensure a smooth, easily executable cessie. ${ }^{27}$ The agreement made by the debtor with a third party will greatly determine the validity and potential risk of receivables used as collateral.

The riskier the receivables the agreement between the debtor and the third party, the riskier the collateral in the debt agreement made by the creditor and debtor. Receivables as collateral are not necessarily receivables that have been issued, or that will automatically exist, but rather the debtor must fulfil certain contractual obligations to third parties first. The practice in Indonesia is different from the practice in the UK, which only allows receivables that have already existed to become collateral. ${ }^{28}$ Thus, in this case, the risk that Indonesian creditors face is far greater than their UK counterparts. In Indonesia, receivables as collateral are still not guaranteed (off the balance sheet) as stipulated in article 9 paragraph (1) of the Fiduciary Guarantee Law. In the UK, there is a terminology used for receivables

\footnotetext{
${ }^{27}$ A perfect cessie is inseparable from the existence of perfect receivables. Without perfect receivables as stipulated in article 613 paragraph (1) of the Indonesian Civil Code, a cessie cannot be executed.

${ }^{28}$ Arthur Yap, 'Mortgage on Civil Law and Common Law Practice' (2015) 51 University of Malaya Law Review Journal.[100].
} 
that can be used as collateral, which are receivables that have been issued and existing and becomes the debtor's property (on the balance sheet). ${ }^{29}$ In this case, the due diligence, especially risk assessment, carried out by the creditor is a form of preventive action to ensure the receivables born from the debtor and third-party agreements are appropriate to be used as collateral.

Considering the existing legal construction, the formulation of the business agreement - especially the agreement between the debtor and the third party - is important and crucial for the validity of the receivables that will be used as collateral for the debtors' debts. In the ideal civil construction, the agreement between the debtor and the third party would have existed prior to the loan agreement between the debtor and creditor. If the agreement between the debtor and the third party that issued the receivables or potential receivables (as referred to in article 9 paragraph (1) of the Fiduciary Guarantee Law) is available on or prior to the creation of the loan agreement, the receivables can be bound by fiduciary guarantees to guarantee debtors' debts to creditors.

This means that the formulation of clauses related to the debtors' debts to third parties becomes very important in the contract. If the conditions of deferment for the issuance of debtor's receivables are difficult to be fulfilled, then commercially, the possibility of imperfect receivables will be high. In the formulation of an agreement between the debtor and a third party, the interests of the debtor are in the clauses related to the conditions of deferment for the issuance of receivables. So, to ensure that the agreement has significant commercial value for the debtor (the receivables can be guaranteed), the conditions of deferment must be minimised.

Thus, when a creditor conducts due diligence on the agreement between the debtor and a third party, the creditor can ensure that he will get high commercial value and low risk on the receivables that become the collateral for the debtor's debt. The more difficult it is to fulfil requirements on the issuance of receivables, the lower the commercial value of the agreement between the debtor and the third

${ }^{29}$ Kelly Yong, 'Comparison between Hongkong and British in the Financing Agreement' (2018) 35 Hongkong Babtist University Legal Journal.[90]. 
party is to the creditor. Conversely, in this case, the formulation of an agreement between the creditor and the debtor is also important as a form of protection for the creditor. An essential part that must be regulated in the debtor and creditor's loan agreement is that if there is no perfect receivable that can be executed as collateral or if the cessie cannot be executed due to the absence of receivables or arising from the legally problematic agreement between the debtor and the third party, the parties will have to formulate a solution towards the repayment of debts to creditors. The creditor also needs to strengthen the representation and warranties clause to ensure that the receivables collateral are free from legal problems.

To ensure that the creditor can execute the fiduciary guarantee in the form of receivables, the contract needs to include a clause regarding the conditions for cancellation. The terms of cancellation refer to the provisions of articles 1266 and 1267 of the Indonesian Civil Code. In this case, the condition for cancellation is if the cessie and debtor receivables originating from third parties that are guaranteed in the form of fiduciary cannot be executed, then by law, the contract made is deemed null, and the guarantor must provide immediate compensation.

\section{Conclusion}

The use of receivables as collateral in business practices in Indonesia based on article 9 paragraph (1) of the Fiduciary Guarantee Law and article 631 paragraph (1) of the Civil Code contains weaknesses that will potentially harm the creditor's position and cause an imbalance in the position between debtor and creditor. In the current regime, the use of receivables and potential receivables as collateral tends to harm creditors. When the debtor is unable to fulfil his obligations to the third party, the collateral will not be issued and becomes practically non-existent.

Likewise, in Indonesia, fiduciary institutions are not like in the UK considering that the registration of receivables as collateral for obtaining fiduciary certificates is only based on a fiduciary deed made by a public notary. As referred to in article 9 paragraph (1) of the Fiduciary Guarantee Law, by allowing collateral binding on receivables that have not necessarily existed due to conditions of 
deferment, the fiduciary institution cannot fully protect the creditor as a fiduciary guarantee holder in case the debtor cannot fulfil his obligations to the creditor.

Adjustments and improvement of fiduciary institutions are needed. In relation to receivables collateral such as in the UK, Indonesia should also establish a credit verification institution. The agency will be tasked to verify the validity of the receivables that will become collateral, so the creditors' rights to payment are guaranteed, and the position between creditors and debtors becomes equal. The existence of valid receivables as collateral will also allow the transfer of receivables through the cessie mechanism as provided in article 631 paragraph (1) of the Indonesian Civil Code. Potential disputes between the parties related to the invalid receivables that become collateral will be accordingly avoided.

The verification of receivables used as fiduciary security, including in this case verification of business contracts between the parties, must be carried out by the Fiduciary Registration Office under the authority of the Ministry of Law and Human Rights. In this case, the authority of the Fiduciary Registration Office must be expanded so that it does not only carry out formal and administrative examinations but also verifies receivables and contract documents.

To authorise verification and expand the authority of the Fiduciary Registration Office, it is necessary to revise Government Regulation Number 21 of 2015 on Fiduciary Security Registration Procedures.

In the preventive aspect, as long as an institution that verifies the validity of the receivables has not been established, the creditor must take preventive measures by himself. Due diligence will be necessary before accepting receivables as collateral for debt. Such due diligence must include the examination of the agreement made between the debtor and third parties - particularly in regards to the potential failure of fulfilment of obligation resulting in non-existent receivables. Furthermore, in the loan agreement between the creditor and the debtor, in addition to the need to guarantee the validity of the receivables collateral, an alternative solution is needed in the event that the receivables collateral turn out to be legally problematic. 
Lastly, to provide legal certainty over the use of receivables as collateral in Indonesia, the government needs to synchronise the regulations pertaining to fiduciary guarantee-particularly by addressing the inconsistency between article 9 paragraph (1) of the Fiduciary Guarantee Law and the provisions of cessie in article 631 paragraph (1) of the Indonesian Civil Code. The establishment of fiduciary institutions, especially related to receivables collateral such as credit verification agency through the amendment of the Fiduciary Guarantee Law is also necessary in accordance with the needs of the business world.

\section{Bibliography}

Central Jakarta District Court Decision No 670/Pdt.G/2017/PN.JKT.PST.

Dean G, 'Financing Transactions in Common Law and Civil Law Countries' (2018) 34 Temple International and Comparative Law Journal.

Dendhana TO, 'Penerapan Prudential Banking Priciple Dalam Upaya Perlindungan Hukum Bagi Nasabah' (2013) 1 Jurnal Lex Et Sociatatis Universitas Sam Ratulangi.

Dughton S, Legal Case on Financial Default (West Publishing St Paul Minnesota 2017).

Fluita AD and I Gusti Ayu K R H, 'Tinjauan Sejarah Lembaga Fidusia Di Indonesia' (2017) 4 Jurnal Repertorium.

Fuady M, Jaminan Fidusia (Citra Aditya Bakti 2003).

Fuady M, Pengantar Hukum Bisnis: Menata Bisnis Modern Di Era Global (2015).

Government Regulation Number 21 of 2015 concerning Fiduciary Security Registration Procedures.

Hessel and King, Financing Case (McGraw Hill Book Publishing 2011).

Hill M, Mortgage History (Intersciences Publishing 2011).

Indonesian Civil Code.

Indonesian Supreme Court Jurisprudence No 1264/K/Pdt/2016. 
Kitt S, Mortgage and Financing Law (Irvin Books Publishing 2017).

Law Number 42 of 1999 concerning Fiduciary Guarantee.

Maquez T, Principle of Financial Feasibility (McGraw Publishing Co Cincinnati Press 2016).

Ndulo C, 'Legal Aspect of Financing Guarantee' (2016) 68 International and Comparative Law Quarterly Journal.

Pardede M and others, Laporan Akhir Penelitian Hukum: Implementasi Jaminan Fidusia Dalam Pemberian Kredit Di Indonesia (Badan Pembinaan Hukum Nasional Departemen Hukum dan Hak Asasi Manusia Republik Indonesia 2006).

Pramono N, Hukum Pembiayaan Dalam Praktik (Andi Offshet 2017).

Prasetiyantono T, Restrukturisasi Pembiayaan Bermasalah (BI Press 2017).

Ramelan Y, 'Perlindungan Terhadap Simpanan Pernah Tercatat Pada Bank, Bukan Suatu Keniscayaan' (2019) 49 Jurnal Hukum dan Pembangunan Universitas Indonesia.

Risalah Keterangan Ahli Akhmad Budi Cahyono dalam persidangan Mahkamah Konstitusi Nomor 18/PUU-XVII/2019 terkait Pengujian Pasal 15 UndangUndang Nomor 42 Tahun 1999 tentang Jaminan Fidusia.

Salim H S, Perkembangan Hukum Jaminan Di Indonesia (Raja Grafindo Persada 2014).

Schletriem P, 'Financing Agreement in Civil Law and Common Law Practice' (2015) 53 Cornell International Law Journal.

Sjahdeini SR, 'Komentar Pasal Demi Pasal Undang-Undang No 42 Tahun 1999 tentang Jaminan Fidusia' (2000) 10 Jurnal Hukum Bisnis.

Suhardi G, Valuasi Jaminan Perbankan (Untag Press 2015).

Susilo MD, 'Lelang Hak Tagih? Mengapa Tidak' (Direktorat Jenderal Kekayaan Negara Kementerian Keuangan, 2018) <www.djkn.kemenkeu.go.id/artikel/ baca/12717/Lelang-Hak-Tagih-Mengapa-TIdak.html $>$ accessed 2 September 2020.

Tedjasaputra L, Pedoman Pengikatan Fidusia Bagi Notaris (Ghalia Indah 2016). 
Thre P, Legal Aspect on Financing Transaction (Little Brown Publishing Canada 2019).

Tim Penyusun Naskah Akademis Undang-Undang Fidusia, Pokok-Pokok Rancangan Undang-Undang Fidusia (Kementerian Hukum dan Hak Asasi Manusia 1999).

Wiriardi M, 'Prinsip-Prinsip Hukum Perjanjian Dalam Kesepakatan Para Pihak Yang Bersengketa Atas Permohonan Intervensi Pihak Ketiga Dalam UndangUndang Nomor 30 Tahun 1999 Tentang Arbitrase Dan Alternatif Penyelesaian Sengketa' (2011) 26 Jurnal Yuridika Universitas Airlangga.

Yap A, 'Mortgage on Civil Law and Common Law Practice' (2015) 51 University of Malaya Law Review Journal.

Yong K, 'Comparison between Hongkong and British in the Financing Agreement' (2018) 35 Hongkong Babtist University Legal Journal.

HOW TO CITE: Rio Christiawan, 'The Use of Receivables as Collateral in Business Practices in Indonesia' (2021) 36 Yuridika. 